\title{
Publisher Correction: Concurrent guiding of light and heat by transformation optics and transformation thermodynamics via soft matter
}

\author{
Wallysson K. P. Barros ${ }^{1}$ \& Erms Pereira $\mathbb{D}^{1,2}$ \\ Correction to: Scientific Reports https://doi.org/10.1038/s41598-018-29866-w, published online 30 July 2018
}

An error occurred during the publication of this Article resulting in the inadvertent omission of the Article and Volume numbers and the publication date from the PDF version of this Article. In addition, maths symbols in the Abstract of the PDF version of this Article were incorrectly rendered. These errors have now been corrected in the PDF version of the Article; the HTML version was correct from the time of publication.

(i) Open Access This article is licensed under a Creative Commons Attribution 4.0 International (c) License, which permits use, sharing, adaptation, distribution and reproduction in any medium or format, as long as you give appropriate credit to the original author(s) and the source, provide a link to the Creative Commons license, and indicate if changes were made. The images or other third party material in this article are included in the article's Creative Commons license, unless indicated otherwise in a credit line to the material. If material is not included in the article's Creative Commons license and your intended use is not permitted by statutory regulation or exceeds the permitted use, you will need to obtain permission directly from the copyright holder. To view a copy of this license, visit http://creativecommons.org/licenses/by/4.0/.

(C) The Author(s) 2018

\footnotetext{
${ }^{1}$ Polytechnic School of Pernambuco, Universidade de Pernambuco, Rua Benica, 455, 50720-001, Recife, PE, Brazil. ${ }^{2}$ Departament of Physics, Universidade Federal Rural de Pernambuco, 52171-900, Recife, PE, Brazil. Correspondence and requests for materials should be addressed to E.P. (email: erms.pereira@ufrpe.br)
} 